\title{
Learning Archeology in the Alandroal': The Institutional Dimension
}

\author{
Bravo Nico ${ }^{1}$, Lurdes Nico ${ }^{2}$, Antónia Tobias ${ }^{3}$, Luísa Carvalho ${ }^{4}$, Florbela Valadas ${ }^{5}$ \\ ${ }^{1}$ University of Évora - PT \\ jbn@uevora.pt \\ ${ }^{2}$ Direcção Regional de Educação do Alentejo - PT \\ Ipnico@drealentejo.pt \\ ${ }^{3}$ University of Évora-PT \\ avieirat@uevora.pt \\ ${ }^{4}$ Instituto Superior Politécnico de Portalegre - PT \\ luisacarvalho80@gmail.com \\ ${ }^{5}$ Câmara Municipal do Alandroal- PT \\ valadasbel@gmail.com
}

\begin{abstract}
According to the information provided by the Portuguese Statistics National Institute, the illiteracy level reaches $9 \%$ in Portugal (17,1\% in the Alentejo). The project Learning Archeology in the Alandroali assumes, as the main purpose, elaborate the complete cartography of the learnings achieved by a resident population in a certain territory (Alandroal/Alentejo/Portugal) and during a certain period of time (1997-2007), crossing its results obtained with the evolution of training proposals system in that same territory and in that same period. Such purpose can be a precious contribution to the understanding of the existent relationships between the learning paths taken by the individuals and the different learning patterns available in a certain place. Indeed, as Rothes (2002) refers, the educational system cannot be reduced to the school system and education-training is not limited to a certain period in one's life, but rather coextensive of that same life. Cavaco (2002) mentions that, the fact that adults rarely participate in formal education activities seems to show the importance that learnings achieved through everyday life activities(in social, professional and convivial environments) have in the group of learnings that are part of the personal portfolio. The methodology to render will be supported by a procedural and instrumental platform where both quantitative and qualitative approaches will take place.
\end{abstract}

Keywords: Learning Style - Educational Cartography - Community Education

\section{Introduction}

In November 2007, one of the bigger research projects in Education began, currently in progress, in Alentejo (Portugal), involving the University of Évora, the Alentejo Regional Education Direction, the Communitarian Development Association SUAO, the regional newspaper Diário do SUL, Alandroal's City Council, being financed by the Foundation for Science and Technology of Portugal

\footnotetext{
'Communication produced by the research project "Learning archeology in the Alandroal" promoted by the Centre for Research in Education and Psychology of the University of Evora (Portugal) and funded by the Foundation of the Science and the Technology (PTDC/CED/81388/2006).

ii idem
} 
(FCT). The research project, named Learning "archaeology" in the Alandroal", took as main objective, to carry out the survey and characterization of the universe of opportunities of learning available e characterized in a given territory (Alandroal), during a decade (1997-2007). In the present communication, will be presented the already available results, that allow a first perception of the educative institutional potential of the territory in study.

\section{The Territory and the Learning: The Context of Portugal}

In present days, in Portugal. there's the perception that, in any territorial context, to the group of institutions with direct responsibility in the availability of learning offers in formal context (learning organized with pedagogic criteria, using appropriate teaching devices and giving academic and/or professional certification), should be added another set, much more complex and rich, of institutions and local contexts generators of non formal learning (which do not grant certification, but possess a reasonable degree of organization and socializing) and informal (that occur in everyday environments proper of the network of social and family relationships in each community reality of residence, work or social contact). The second set of institutions, plays a bigger role in the training of individuals in the rural Portuguese territories due to the lack of formal learning spaces, to a strong associative spirit and of civic and social participation still present in the heart of small Portuguese communities and realized in the existence of a universe of institutions from civil society. The territory is, in this context, a structural element of all social dynamics that in it are generated and developed. It's in this context that Ferragolo da Veiga (2005:233) states that there are "two issues considered key to understanding change in rural areas: a space conception that considers the nature of it's territory, according to their accumulated history and the constellation of social, local and global relations; and a player with reflective capacity and action, that does not remove importance to the structural dimension, but with it is closely associated".

In Portugal, with the implementation of the processes of RVCC (Recognition, Validation and Certification of Skills), from the 2000 year, it was possible to begin to have a perception clearer of the relative importance of the institutions and local contexts in the set of achieved learning by adult along their course of life. In reality, based on a matrix approach in which the life stories began to take a determinative paper - so it is through this approach that are built portefólios reflexive, in which the identifies significant learning for the construction / development of skills that, later, will be recognized and certification. There has become possible to have a closer notion of what is the true importance of the educating action of the local institutions of many different kinds: enterprises, associations of development, sports, of solidarity, cultural, recreational, youthful and of religious extent. Even mores so, Arroteia et al say(2000:157), "the designation of the educational map contemplates the existence of other educational spaces apart from the school, which should not be ignored at present."

The training of individuals is, in this context, a dynamic process, that will reflect structurally the learning opportunities, that exist local and territorial. Therefore, detailed knowledge of the local institutions and promoters contexts of learning opportunities is essential to the complete map of the educational reality of a territory (Imaginário, 2007:27), beyond giving us a perspective on the degree of community mobilization for the associative practice (Lima \& Erasmie, 1982:132). 
Naturally, this conceptual exercise assumes that the geographic, demographic, social, economic and social dimensions influence the geometry of the learning map of each area and each individual. A map where all the nodes of the network, should be considered, because they all are, in fact, coordinates the individuals pass through in their vital trajectories (Nico, 2008:14). Especially because, at present, "the hegemony of a school and the educational monopoly of the school have been coming to be put in question in the field of principles (development of continuing education) but also in the field of practice (Canário, 1996:7).

The family and social network are other key elements of this map in the learning of each individual and their contribution to the qualification is now more visible in the content of reflective portfolios, which have been built by hundreds of thousands of Portuguese.

One learns everywhere, at any moment, in any circumstance, with anyone, always with some objective. If we think that any "educative act is immersed in a determined context, that is the synthesis of factors like the time, the space, the history, the experiences, the projects and the natural circumstances in which the agents of educational practice are developed" (Gómez, Freitas and Callejas, 2007:177), the study and the consideration of the educative potential of the territories is, in the present, one of the basic preoccupations in the drawing and realization of local politics promoters of a model of human, cultural, economical and social development from an array of sustainability and of narrowing of the cooperative work, based in partnerships synergistic and generators of the endogenous resources. In the territory object of our study (County of Alandroal located in the Alentejo region, to the South of Portugal), as in any other geographical, social and cultural context, there is a universe of learning opportunities.

The concept of educating city, incorporating such thinking, points, in reality, to the promotion of territories generators and promoters of good conditions for the exercise, with good quality, of the Right to Education, by individuals who in them reside or in them are involved. This is the background that the local territories are assumed also, as spaces of "restoring legitimacy of public action" (Ferreira, 2005:102).

\subsection{The Territory of Alandroal}

It was based on the assumptions outlined above, in 2007, that a research team from the CIEP (Center for Research in Education and Psychology at the University of Évora) initiated the study of a given area: the County of Alandroal. This territory has an area of $544.86 \mathrm{~km} 2$ and an adult population (aged 18 years or more) of 5582 individuals. It consists of six parishes: $\mathrm{N} \mathrm{a}$ Senhora da Conceição (1570 individuals), Santiago Maior (2172), Terena (757) São Brás dos Matos (353), Capelins (585) and Terena (145). Located geographically within the least populated region of the country (southeast Portugal), the Alandroal has low social and economic levels (52.19\% of the average GDP per capita of Portugal) and weak education indicators that show, for example, an illiteracy rate of $21 \%$ (INE, 2002). Accordingly, in the county of Alandroal, the qualification of adult individuals, will without a doubt refer us for journeys built away from the spaces of school and formal learning. It were the non-formal and informal learning contexts, available in the relational and institutional fabric of small communities of the territory, that have assumed 
themselves, probably, like the spaces more available and, therefore, more present in the construction and structuring of educational projects of individuals.

\section{Strategic and Methodological Procedures}

In the circumstances described, we believe that the trend in the research, started in 2007, would have to go, necessarily, through the census of all institutions operating in the territory of the county of Alandroal, regardless of their area of activity. To this end, we assumed, as an institution any entity, legally existing and fiscally active. As an institutional learning, it was considered every learning opportunity identified (in any context) that revealed a minimum of intentionality and structure and that had resulted from the action of the institutions surveyed in the study period (1997-2007). To ensure appropriate conditions for the realization of the research protocols were established with local authorities (Municipal Council and Parish Councils), the Regional Directorate of Education of the Alentejo, the Alentejo Regional Branch of the Institute of Employment and Vocational Training and the Group of Schools of Alandroal. Since the beginning of the project concretion, the Alandroal City Council has made available, to the research project, an office, in its physical facilities, and a full time employee with appropriate academic training to the project objectives.

Between January 2008 and today, a team of researchers has been on the ground to achieve the methodological procedure of research, according to the following phases:

- 1st Phase (Janeiro/2008-Junho/2009): Implementation of the Learning Institutional Questionnaires I and II (QAI I and QAI II) to 286 institutions who agreed to participate, in a universe of 328 institutions identified in the area. This first phase was designed to identify and characterize the universe of existing institutions in the area and learning which they organized and made available;

- 2nd Phase (ongoing): Application of the Questionnaire of Personal Learning (QAP) to a semi-stratified sample of 1084 people registered in the parishes of the area under study. This second phase is to identify and characterize the universe of learnings achieved by the adult population in the territory (Alandroals County) during a decade (1997-2007).

\section{The Available results: institutional dimension}

From the application and posterior analysis of the gathered information by QAI I and II, in all of Alandroal, it is possible, to the date of this communication, to present the following data, already available related to the inquired institutions:

i) There were 328 identified institutions, 286 of which were inquired, corresponding to a $86.2 \%$ coverage rate, according with the distribution indicated in Table 1: 
Table 1 - Number of institutions in Alandroal's county (by parish)

\begin{tabular}{|l|c|c|c|}
\hline \multicolumn{1}{|c|}{ Parish } & \multirow{2}{*}{$\begin{array}{c}\text { Institutions } \\
\text { Identified }\end{array}$} & $\begin{array}{c}\text { Absolute } \\
\text { Frequencies (n) }\end{array}$ & $\begin{array}{c}\text { Relative } \\
\text { Frequencies (\%) }\end{array}$ \\
& 119 & 101 & 84,5 \\
\hline N. Senhora da Conceição & 101 & 89 & 85,1 \\
\hline Santiago Maior & 45 & 40 & 88,9 \\
\hline Terena & 32 & 28 & 87,5 \\
\hline São Brás dos Matos & 18 & 16 & 88,9 \\
\hline Capelins & 13 & 12 & 92,3 \\
\hline Juromenha & $\mathbf{3 2 8}$ & $\mathbf{2 8 6}$ & $\mathbf{8 8 , 1}$ \\
\hline Total & & & \\
\hline
\end{tabular}

ii) With regard to the statutory nature, legal and functional nature, it was found that private entities predominate $(75.5 \%)$, according to the indicated in chart 1 and 2 .

Chart 1: Statutory Nature(\%)

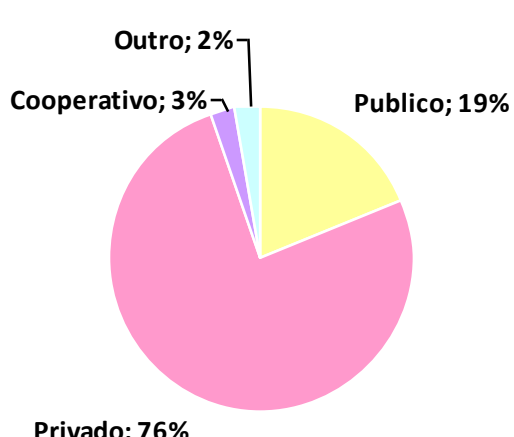

Privado; 76\%
Chart 2: Legal and Functional Nature (\%)

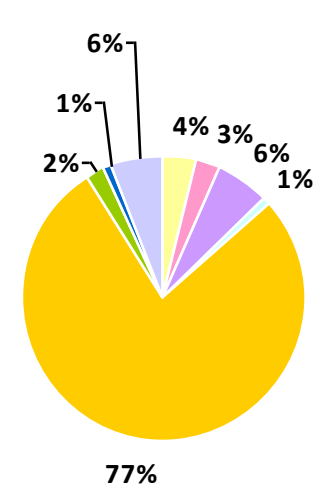

Autarchy
IPSS
Association of local
development
Youth Association
Business
Cooperative
Educational
Establishment
Other

iii) According to the economic activity groups (and given the Portuguese Classification of Economic Activities ${ }^{\text {iii }}$ ), the most represented, in the study

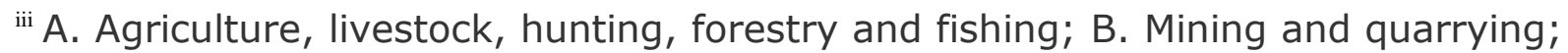
C. Manufacturing F. Construction, G. Wholesale and retail trade, repair of motor vehicles and motorcycles; I. Lodging, restaurant and alike J. Information and Communication Activities, K. Financial and insurance Activities; M. Professional, scientific and technical activities; N. Administrative and support services; $O$. 
territory, are wholesale trade and retail (25.5\%), housing, restaurants and alike (24\%) and agriculture, animal production, hunting, forest and fishing (12.6\%) as shown in chart 3.

Chart 3: Institutions, by area of economic activity* (\%)

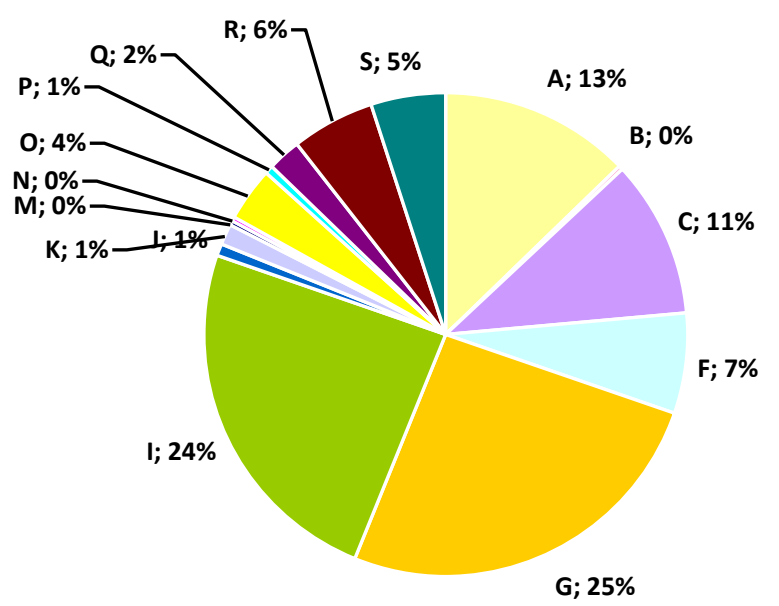

iv) When carrying out the reading on the number of individuals associated with each area of activity, it appears that there were differences in relation to previous findings. It appears that the number of recreational, cultural and sporting activities have a significant presence in the county, because they involve, according to data from the QAI II, 3498 people, which shows a strong civic and social dynamics of the population;

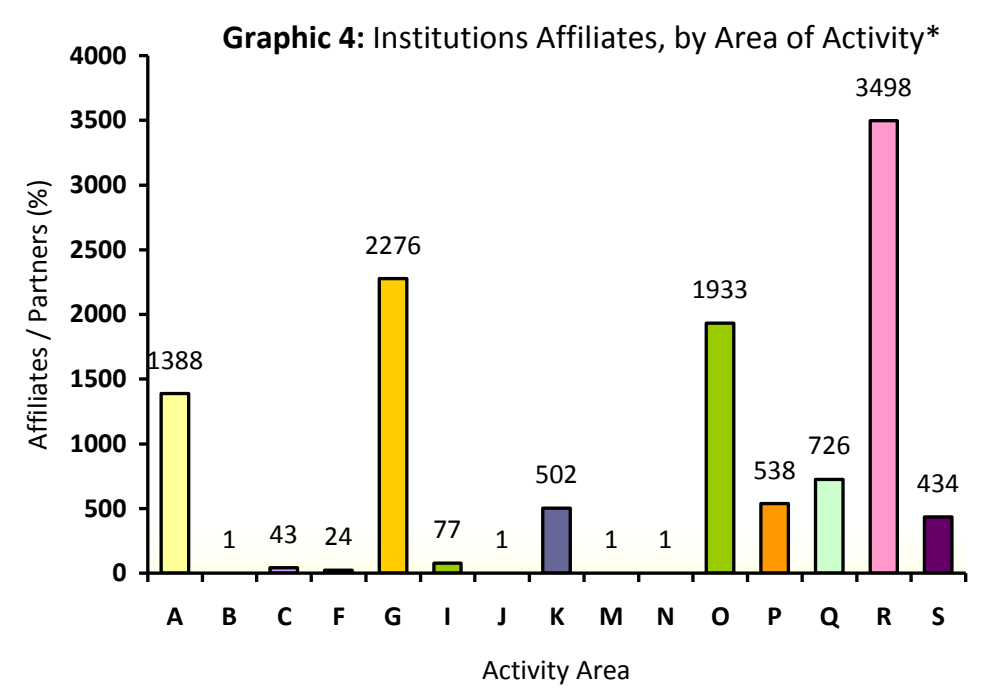

v) $33.2 \%$ of institutions surveyed have revealed to possess the Annual Plan of Activities. In this group, are mostly, companies, associations, private institutions of social solidarity and of a public office;

Public administration and defense, compulsory social security; P. Education; Q. Human health activities and social support; R. Art Activities, entertainment, sport and recreation; S. Other activities and services; s / resp. No response. 
vi) most institutions run all year (93\% of cases). Only 12 are active seasonally (4.2\% of cases);

vii) The hours of operation, as well as public access to the institution is complete: it works on weekdays in the morning and / or afternoon and is open to the public;

viii) The personnel that integrates the institutions is mostly paid. However, there is the existence of $9 \%$ of individuals who is on a voluntary basis;

ix) Most institutions have proper accounting (81.5\%), often using the services of an individual officer $(45.5 \%)$, or an accounting firm. In some cases, this task is performed by the institution $(12.6 \%)$;

x) $26 \%$ of organizations hold meetings of the executive body (Management) and $17.1 \%$ promotes deliberative meetings (General Assembly), with some regularity;

xi) $30 \%$ of the institutions cooperate with other institutions. This cooperation is established, formal and on record in $81.4 \%$ of cases;

xii) there were identified 689 opportunities for learning in the universe of reporting institutions (286), according to the distribution that is presented next:

\section{Table 2 - Number of learnings in Alandroal's county (by parish)}

\begin{tabular}{|l|c|c|c|}
\hline \multicolumn{1}{|c|}{ Parish } & $\begin{array}{c}\text { No of } \\
\text { institutions } \\
\text { inquired }\end{array}$ & $\begin{array}{c}\text { No of learning } \\
\text { opportunities } \\
\text { identified }\end{array}$ & $\begin{array}{c}\text { Index of } \\
\text { institutional } \\
\text { learning }\end{array}$ \\
\hline \begin{tabular}{l|c|c|c|}
\hline N. Senhora da \\
Conceição
\end{tabular} & 101 & 257 & 2,5 \\
\hline Santiago Maior & 89 & 255 & 3.0 \\
\hline Terena & 40 & 73 & 1,8 \\
\hline São Brás dos Matos & 28 & 28 & 1,0 \\
\hline Capelins & 16 & 29 & 1,8 \\
\hline Juromenha & 12 & 47 & $\mathbf{2 , 4}$ \\
\hline Total & $\mathbf{2 8 6}$ & $\mathbf{6 8 9}$ & \\
\hline
\end{tabular}

xiii) The parish Juromenha, although it is one that fewer people and institutions reveals, proved to be the local context with higher institutional learning (3.9), considering the number of learning identified in relation to the number of institutions surveyed and individuals resident. The parish of São Brás dos Matos turned out to be the local context with the lowest level of institutional learning (1.0), according to the same criteria mentioned above; 
xiv)Regarding the content of learnings provided by the institutions, the following table with their distribution is presented:

Table 3 - Learnings offered by institutions (1997-2007)

\begin{tabular}{|c|c|c|}
\hline Learning Cluster & $\begin{array}{l}\text { Absolute } \\
\text { Frequency }\end{array}$ & $\begin{array}{c}\text { Relative } \\
\text { Frequency } \\
(\%)\end{array}$ \\
\hline $\begin{array}{l}\text { Activities related to Electronic Devices, } \\
\text { Technological Innovation and Machinery }\end{array}$ & 138 & 20,0 \\
\hline $\begin{array}{l}\text { Activities for Health and Consumer } \\
\text { Protection }\end{array}$ & 126 & 18,5 \\
\hline Activities of trade and services & 52 & 7,5 \\
\hline $\begin{array}{l}\text { Activities related to the Leisure, leisure } \\
\text { education }\end{array}$ & 37 & 5,4 \\
\hline Activities of Training and Education & 34 & 4,9 \\
\hline $\begin{array}{l}\text { Activities of the Information Technology } \\
\text { and Communication }\end{array}$ & 34 & 4,9 \\
\hline Management Activities & 28 & 4,1 \\
\hline Agro-Livestock Activities & 27 & 3,9 \\
\hline $\begin{array}{l}\text { Administrative Activities, accounting and } \\
\text { finance }\end{array}$ & 49 & 7,1 \\
\hline Planning Territory Activities & 19 & 2,8 \\
\hline Physical Activity and Sport & 16 & 2,3 \\
\hline Others $^{\mathrm{iv}}$ & 127 & 18,5 \\
\hline Total & 689 & 100,0 \\
\hline
\end{tabular}

xv) 61 institutions surveyed (8.9\%) did not organize any activity that involves learning, during the study period (1997-2007);

xvi) The highest relative frequency of learnings offered by the institutions of the county of Alandroal, relate to maintenance activities of electronic equipment, with the Technological Innovation and Industrial Machinery $(20 \%)$, possibly a result of business and small existing industries in which there is a frequent need to replace and upgrade equipment;

xvii) Activities related to the provision of health care and consumer protection $(18.5 \%)$ also potentiate the organization of learnings, by the

iv 37 clusters with an index less than 2\% each. Particularly learnings in the following areas: Partnerships, Initiatives and Entrepreneurship, Geriatrics, Civil Protection, Communication, Logistics, Music Services, Restaurants, Health, Decoration, Entertainment, Law, Languages, Biochemistry, Hunting, Culture, Industry, Reading, Social, Social, Craft, Cinematography, Hospitality and Lodging, Mathematics, Painting, Religion, Agriculture and Livestock, authority, hairdresser, Dance, Photography, Interpretation, Theater, Weaving, Tourism 
institutions. Evidence that perhaps reflects the significant role of institutional activities aimed at a literate and young population;

xvii) $63 \%$ of those involved in the institutional learningswere the owners of the institutions. The learning situations identified were episodic (in $38.4 \%$ of cases) or permanent $(31.6 \%)$;

ixx) $55.9 \%$ of respondents said they didn't certified the learning that took place, which demonstrates a low concern for the relevance of academic knowledge and skills built or strengthened.

\section{Final Reflection}

At the moment research project is, we understand that the reality, thathas been possible to perceive, has proved an interesting subject of study, with obvious potential for exploration. In fact, the universe of existing institutions overcame by a large extent, the initial expectations and the identified set of learnings is clearly beyond what was imaginable, in an area as small and in a demographic so low.

We have now a clear perception that the test - still ongoing - to the learnings identified will reveal a universe a still unknown, of non-formal and informal education contexts, but decisive and significant in the qualification process for individuals residing in the county ofAlandroal.

Given the already evident differences between the various parishes of the territory, at the level of institutional qualification, it is expected that the learnings achieved by the resident population in each context would, therefore, reveal multiple standards.

One certainty, however, may already be taken: being the territory a determining factor in the process of qualifying individuals and institutions, it is clear and fundamental that in each territorial context, there should be a proper mapping of all existing learnings. Without this exercise, conceptually and institutionally, broad and rigorous, you can not build a true educational map, as a real and participated tool to support local and regional management of Education and Training.

\section{Final Reflection}

Arroteia, J. et al (2000). Gafanha da Nazaré: escola e comunidade numa sociedade em mudança. Lisbon: Institute of Education Innovation.

Canário, R. (1996). "Nota de Apresentação". in Natália Alves et al. A escola e o espaço local: políticas e actores. Lisbon: Institute of Education Innovation.

Ferragolo da Veiga, J. (2005). Território e Desenvolvimento Local. Oeiras: Celta Editora.

Ferreira, F. (2005). O Local em Educação: animação, gestão e parceria. Lisbon: Foundation Calouste Gulbenkian. 
10 Proceedings $2^{\text {nd }}$ Paris International Conference on Education, Economy and Society - 2010

Gómez, J., Freitas, O. \& Callejas, G. (2007). Educação e Desenvolvimento Comunitário: perspectivas pedagógicas e sociais da sustentabilidade. Porto: Profedições.

Lima. L. \& Erasmie, T. (1982). Inquérito às Associações do Distrito de Braga. Braga: Unity of Education of Adults of the University of the Minho.

Nico, B. (2008). "Aprender no Interior português: Vértices para um pensamento integrado e uma acção responsável". in Bravo Nico (Org.). Aprendizagens do Interior: reflexões e fragmentos. Mangualde: Edições Pedago. 